\title{
Intracorneal bacterial colonization in a crystalline pattern
}

\author{
M. Nanda ${ }^{1}$, H. Kaz Soong ${ }^{2}$, M.P. Krenz ${ }^{3}$, and W.R. Green ${ }^{1}$ \\ ${ }^{1}$ Eye Pathology Laboratory, Wilmer Ophthalmological Institute and Department of Pathology, \\ Johns Hopkins Medical Institutions, Baltimore, Maryland, USA \\ ${ }^{2}$ Department of Ophthalmology, University of Michigan, Ann Arbor, Michigan, USA \\ ${ }^{3}$ Muskegon, Michigan, USA
}

\begin{abstract}
We report the case of a 78-year-old woman who developed an intrastromal bacterial colonization 22 months after penetrating keratoplasty. Slit-lamp examination revealed discrete, finely branched, fernlike stromal opacities, which were histopathologically found to be large intrastromal aggregates of gram-positive cocci with almost no inflammatory cell response.
\end{abstract}

\section{Introduction}

Bacterial infections complicating corneal transplantation are seen in up to $4.9 \%$ of patients (Tuberville and Wood 1981). Intrastromal bacterial colonization in a crystalline pattern is an uncommon presentation of postkeratoplasty keratitis. These finely branched opacities have previously been reported by two authors (Gorovoy et al. 1983; Meisler et al. 1984). Meisler et al. has referred to the lesions as infectious crystalline keratopathy. Of the four cases reported, three had previous corneal transplant surgery. Contrary to the expected, none of the cases showed inflammatory cells despite the presence of alpha-hemolytic streptococci in two

Offprint requests to: W. Richard Green, M.D., Eye Pathology Laboratory, Johns Hopkins Hospital, 600 N. Wolfe Street, Baltimore, MD 21205, USA patients. We present a clinicopathologic case report of an unusual intrastromal bacterial colonization complicating corneal transplantation.

\section{Case report}

A 78-year-old woman presented with bilateral dense cataracts, bilateral Fuchs' dystrophy, and corrected vision of counting fingers at $2 \mathrm{ft}$., right eye, and $20 / 400$, left eye. She underwent a combined penetrating keratoplasty, extracapsular cataract extraction, and insertion of a posterior chamber lens implant in her right eye in February 1983. The donor button was obtained after death from a whole eye that was stored for $6 \mathrm{~h}$ in a moist chamber at $4^{\circ} \mathrm{C}$. The postoperative course was uneventful until May 1983 when a small suture abscess developed on the temporal side of the donor cornea. Culture of material from the lesion demonstrated beta-hemolytic streptococcus; the lesion responded well to topical and subconjunctival gentamicin. She continued at the time to have $20 / 25$ best-corrected vision in the right eye.

In March 1984, a clouding at the graft-host junction superiorly on the temporal side with no corneal epithelial staining was seen. This responded well to topical steroids and gentamicin, but in July 1984, she had a sudden onset of stromal melting in the area on the donor side, resulting
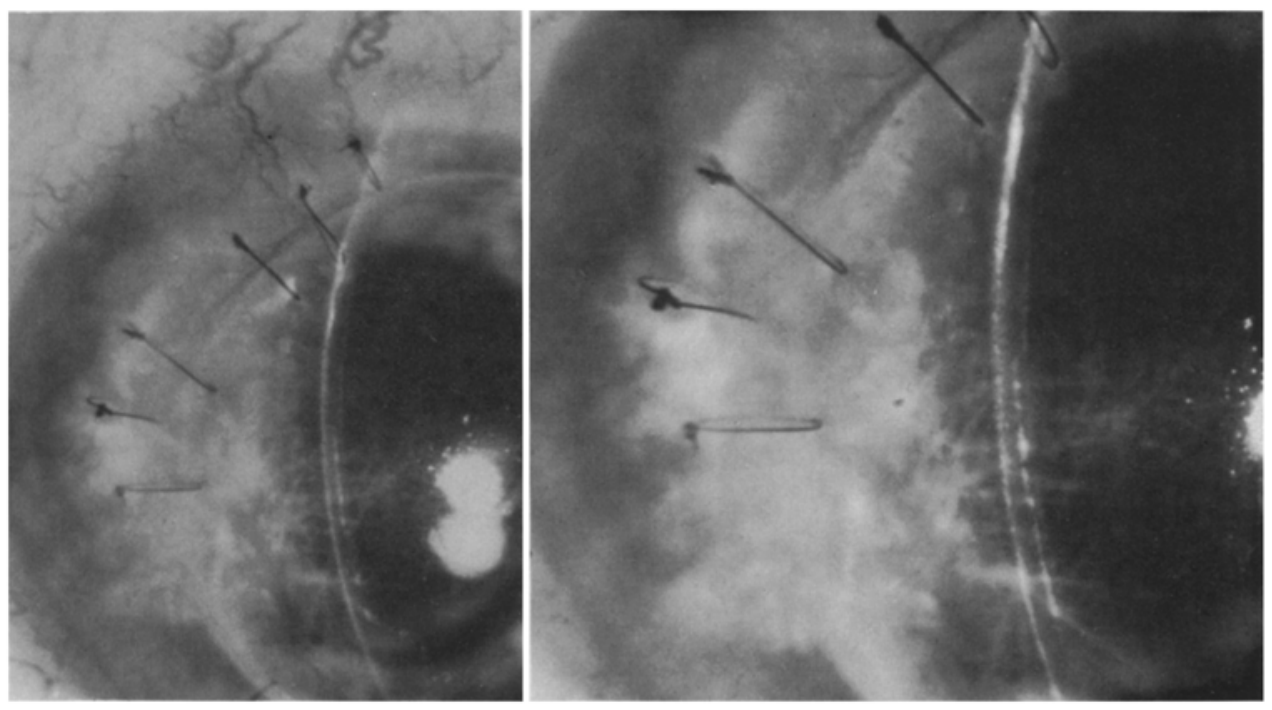

Fig. 1. Slit-lamp appearance of the discrete, white infiltrates deep in the stroma of donor and recipient originating from the donor-host interface 22 months after penetrating keratoplasty 

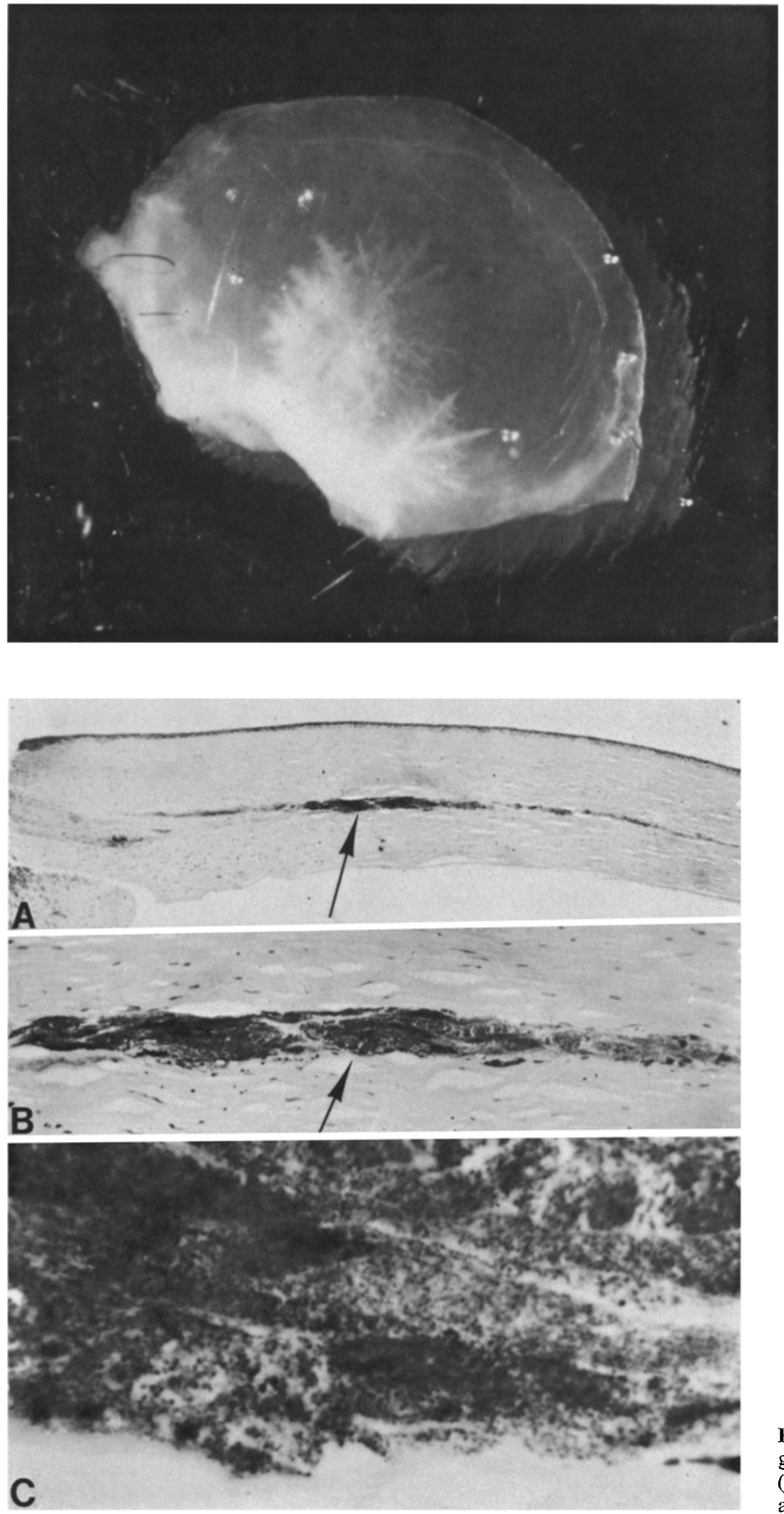

Fig. 2. Gross appearance of fernlike corneal opacity involving much of the center of the corneal button
Fig. 3A-C. Light microscopic appearance of gram-positive cocci at midlevel of corneal stroma (arrows) with rare inflammatory cells. (Brown and Hopps: A $\times 10 ; \mathbf{B} \times 160 ; \mathbf{C} \times 400$ ) in a small descemetocele and the steroids were rapidly tapered. The edges of the host and graft were curetted of a soft tissue and the graft-host interface in the area was reinforced with interrupted $10-0$ nylon sutures.
In September 1984, the patient returned with sudden, painless reduction in vision in the right eye. Hypopyon and moderate vitritis were noted in the eye. In addition, there was a samll area of epithelial staining over one of the infero- 


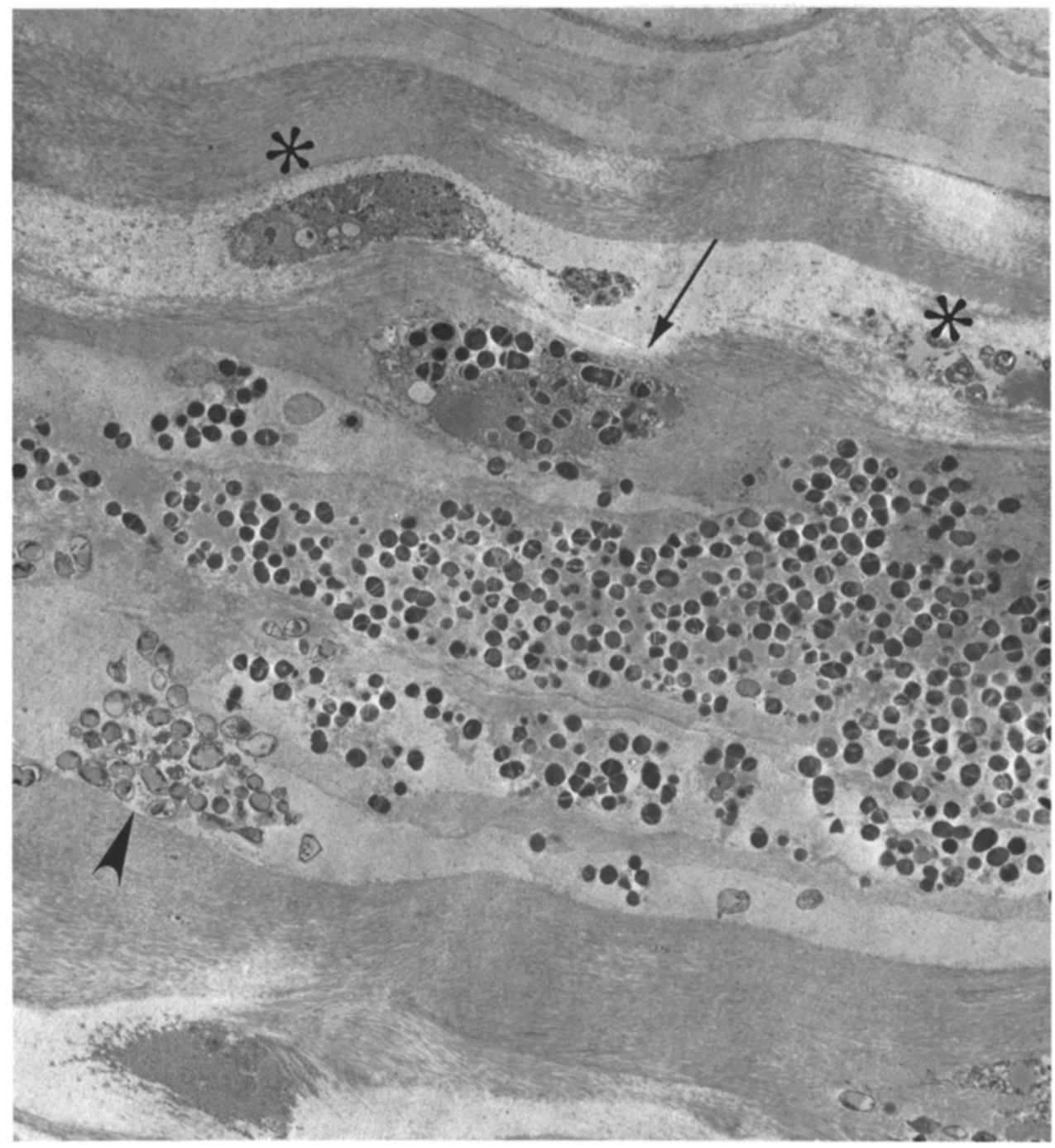

Fig. 4. Area shows bacteria in the deep corneal stroma.

Degenerating bacteria are present at one area (arrowhead). Some bacteria are within keratocytes (arrow). Degenerated cells (asterisk) are present in this area. $(\times 4,000)$ temporal sutures. Surface scrapings were negative for organisms. Within a month, treatment with subconjunctival and topical gentamicin and topical steroids had cleared the reaction. Four more similar episodes associated with uveitis and vitritis were noted.

In December 1984, the patient's right eye vision was reduced to counting fingers at $2-3 \mathrm{ft}$. The graft on slit-lamp examination was clear except for an area in the deep stroma temporally where small, relatively discrete branching infiltrates were present (Fig. 1). Epithelium was intact over the entire corneal surface and the temporal periphery of the corneal graft was thinned by about $50 \%$. The anterior chamber had a moderately severe cell and flare reaction without hypopyon, and the vitreous had a mild cellular reaction. Mild opacification of the posterior capsule of the lens was present. The posterior chamber lens was in good position. Slit-lamp examination of the left eye was unremarkable except for Fuchs' dystrophy and a dense cataract. Central corneal thicknesses were $0.46 \mathrm{~mm}$ in both eyes. Schirmer's test registered $12 \mathrm{~mm}$ in the right eye and $8 \mathrm{~mm}$ in the left eye 5 min after topical anesthetic. Corneal sensations were absent in the right eye and decreased in the left eye. Tensions by applanation $(\mathrm{mm} \mathrm{Hg}$ ) were $32 \mathrm{OD}$ and $17 \mathrm{OS}$. The fundus examination of the right eye showed marked vitreous reaction but no evidence of retinal vasculitis, edema, or detachment. A vitreous tap showed rare polymorphonuclear leukocytes and no microorganisms. Within 1 week, the inflammatory reaction had cleared on topical and subconjunctival gentamicin.

The patient had a recurrent episode of uveitis after the initial clearing in late January 1985. Again, she responded to the use of topical and subconjunctival gentamicin, and visual acuity improved to $20 / 70$ in the right eye. Late in February 1985, the patient had keratic precipitates with overlying epithelial defects involving the temporal portion of the graft.

On March 3, 1985, further thinning of the graft temporally resulted in a perforation with consequent loss of the anterior chamber. White intrastromal infiltrates were present in the donor and host cornea near the area of perforation, but the graft was clear nasally. A repeat penetrating keratoplasty, combined with removal of the intraocular lens and an anterior vitrectomy, were performed on the right eye. Samples of the excised cornea and vitreous were submitted for fungal, anaerobic and aerobic bacterial, and pathological examination. Three months after the second keratoplasty, the best-corrected vision was $20 / 40$, and there was no evidence of infection in the graft or host tissues. 

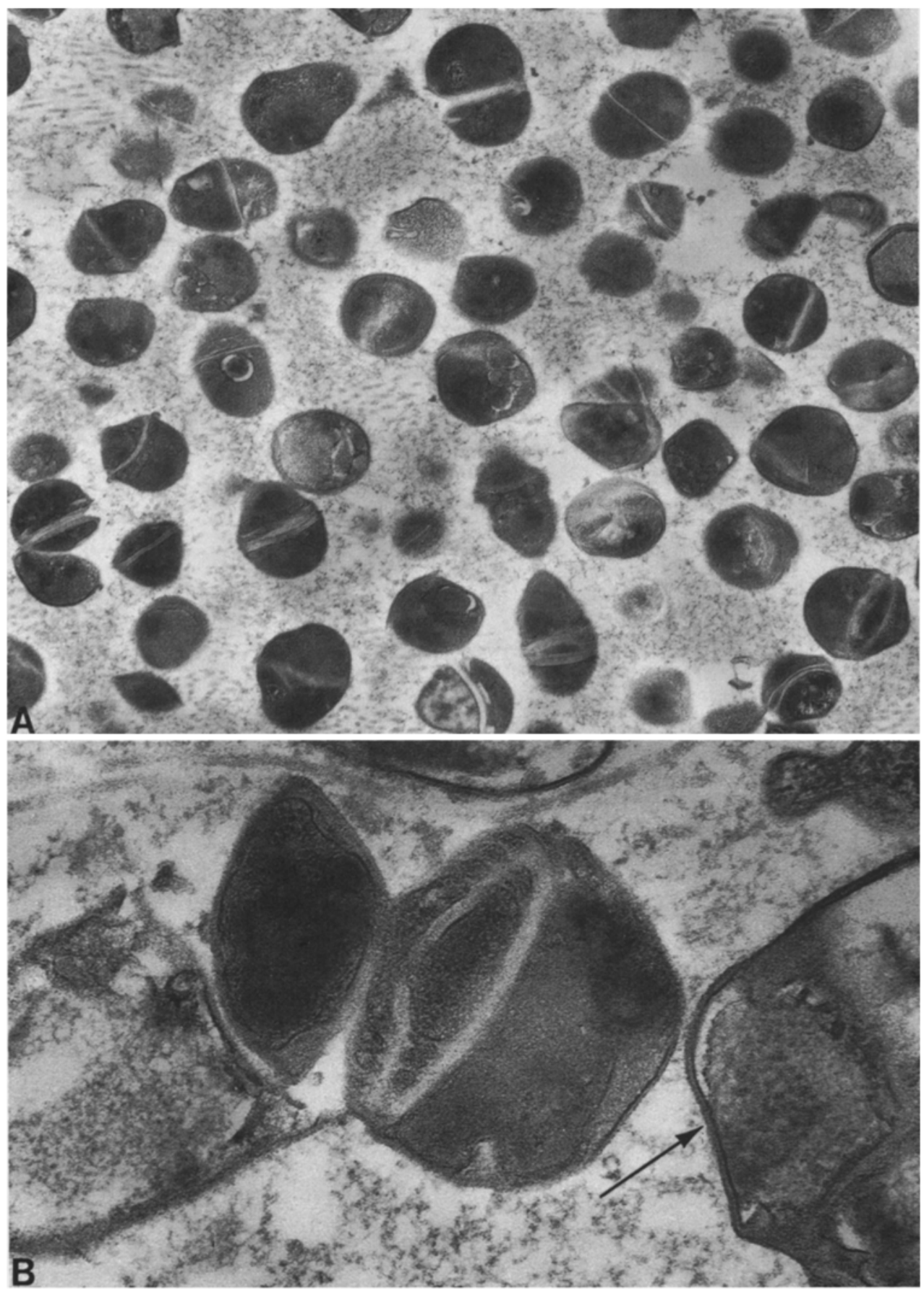

Fig. 5. A Most organisms are replicating in one or more planes of division $(\times 28,000)$.

B Higher power shows

characteristic trilaminar cell wall (arrow) of the bacteria. $(\times 80,000)$

\section{Results}

The gross specimen was a partial corneal button from the repeat penetrating keratoplasty, measuring $8.0 \mathrm{~mm}$ in its greatest diameter. A white, midstromal and finely branched lesion extended superonasally from the area of corneal melt and perforation. The discrete, fernlike opacity measured $5.0 \mathrm{~mm}$, its base was located inferotemporally, and it involved the visual axis (Fig. 2).

Microscopic examination of the corneal button (Fig. 3) disclosed a normal, intact corneal epithelium, except for slight intracellular edema at the inferior margin. Diffuse, but very mild, keratitis was present throughout the stroma. A more marked inflammatory cell infiltrate was present at the inferior edge. A midstromal lesion, involving about $60 \%$ of the diameter of the section, was present. The area, using gram stain, consisted of many gram-positive cocci. Methenamine silver stain was negastive for fungi but differentially stained the bacteria.

A portion of the formaldehyde-fixed cornea was processed for transmission electron microscopy. Numerous round-to-oval bacteria, measuring 0.4 to $0.6 \mu \mathrm{m}$ in diameter (Fig. 4), were seen in the corneal stroma. The surrounding collagen was intact. Some of these bacteria were located in fibrocytes and macrophages. Some cells appeared in various stages of degradation. Many bacteria were in division with one cleavage plane (Fig. 5). On cross section, some bacteria had a trilaminar outer covering composed of two 
Table 1. Cases of intracorneal bacterial colonization in a crystalline pattern

\begin{tabular}{|c|c|c|c|c|c|}
\hline Authors & Case history & Interval & Organism & Treatment & Outcome \\
\hline $\begin{array}{l}\text { Gorovoy et al. } \\
(1983)\end{array}$ & $\begin{array}{l}\text { 69-year-old woman with penetrating } \\
\text { keratoplasty for aphakic bullous } \\
\text { keratopathy }\end{array}$ & 6 months & Not cultured & $\begin{array}{l}\text { Antibiotics, } \\
\text { steroids }\end{array}$ & $\begin{array}{l}\text { Repeat PK } 11 \text { months } \\
\text { postoperatively }\end{array}$ \\
\hline \multirow[t]{3}{*}{$\begin{array}{l}\text { Meisler et al. } \\
(1984)\end{array}$} & $\begin{array}{l}\text { 83-year-old man with PK for } \\
\text { aphakic bullous keratopathy }\end{array}$ & 3 months & $\begin{array}{l}\text { Negative } \\
\text { culture }\end{array}$ & $\begin{array}{l}\text { Antibiotics, } \\
\text { steroids }\end{array}$ & $\begin{array}{l}\text { Residual central } \\
\text { scarring }\end{array}$ \\
\hline & $\begin{array}{l}67 \text {-year-old man with chronic } \\
\text { herpes simplex keratouveitis and } \\
\text { chronic open-angle glaucoma }\end{array}$ & $\begin{array}{l}\text { Not } \\
\text { applicable }\end{array}$ & $\begin{array}{l}\text { Alphahemolytic } \\
\text { streptococci }\end{array}$ & $\begin{array}{l}\text { Antibiotics, } \\
\text { steroids, } \\
\text { anti-glaucoma }\end{array}$ & $\begin{array}{l}\text { Scarring, } \\
\text { neovascularization }\end{array}$ \\
\hline & $\begin{array}{l}\text { 44-year-old man with PK for perfo- } \\
\text { rated herpes simplex corneal ulcer }\end{array}$ & 36 months & $\begin{array}{l}\text { Alphahemolytic } \\
\text { streptococci }\end{array}$ & $\begin{array}{l}\text { antibiotics, } \\
\text { steroids, } \\
\text { anti-glaucoma }\end{array}$ & Residual edema \\
\hline Present case & $\begin{array}{l}\text { 78-year-old woman with PK for } \\
\text { Fuchs' dystrophy }\end{array}$ & 22 months & $\begin{array}{l}\text { Negative } \\
\text { culture }\end{array}$ & $\begin{array}{l}\text { Antibiotics, } \\
\text { steroids }\end{array}$ & $\begin{array}{l}\text { Repeat PK } 25 \text { months } \\
\text { postoperatively }\end{array}$ \\
\hline
\end{tabular}

thin electron-dense layers (each 4-6 nm thick), separated by a less dense layer about $7 \mathrm{~nm}$ thick. A nucleus, mesosomes, and other organelles were present inside these organisms.

The results of fungal, aerobic bacterial and anaerobic bacterial cultures were negative.

\section{Discussion}

Intrastromal infiltrates or opacities as an indication of corneal graft rejection have been previously described (Krachmer and Alldredge 1978; Mason et al. 1984; McCulloch 1971). We report a rare form of intrastromal bacterial colonization, which occurs in a crystalline pattern, and it is unusual because of the minimal vascular and inflammatory response despite progressive disease. Although cultures were negative, light and electron microscopic evidence is conclusive for gram-positive cocci (Holt 1980). This case ist remarkable because of the indolent nature of the colonization, the prolonged postoperative period before infection, and the appearance of the lesion. Similar cases, with some notable exceptions, have been reported by Gorovoy et al. (1983) and Meisler et al. (1984) (Table 1).

Intrastromal bacterial colonization has been demonstrated to occur from 3 months to 3 years after a pentrating keratoplasty; one case reported by Meisler et al. (1984) had no prior history of surgery. Despite reports indicating that bacterial contamination of donor corneas is a route of infection following penetrating keratoplasty (Khodadoust and Franklin 1979; Matoba et al. 1984), this route is unlikely in this case because of the long interval between the lesions and surgery. Gorovoy and co-workers (1983) believed that a suture tract was the initial site of infection in their case. Exposed monofilament sutures leading to endophthalmitis has been reported by Confino and Brown (1985). In our case, an epithelial defect, combined with the presence of sutures through an area of stromal melting, may have predisposed to the infection.

Two interesting aspects of this case are the crystalline appearance of the infiltrates on clinical examination and the relatively mild inflammation associated with the keratitis. The mild inflammatory cell infiltrate associated with the bacteria may be related to the low pathogenicity of the bacteria, the avascular cornea, and to possible local and systemic impairment of the defense mechanisms. The reasons for the paucity of the inflammatory reaction are not apparent in this patient. There was no history of or evidence for conditions which might be risk factors, such as diabetes, dry eyes, alcoholism, atopic dermatitis, or immune disorders.

We conclude that the fernlike opacification of the cornea is due to a lamellar invasion of bacterial colonies along the planes of least resistance. The clinical appearance of a fernlike crystalline opacity in the corneal stroma after keratoplasty suggests intrastromal bacterial colonization.

\section{References}

Confino J, Brown SI (1985) Bacterial endophthalmitis associated with exposed monofilament sutures following corneal transplantation. Am J Ophthalmol 99:111-113

Gorovoy MS, Stern GA, Hood CI, Allen C (1983) Intrastromal noninflammatory bacterial colonization of as corneal graft. Arch Ophthalmol 101:1749-1752

Holt SC (1980) Bacteria. In: Johannessen JV (ed) Electron microscopy in human medicine: infectious agents, vol. 3. McGrawHill, New York, pp 143-153

Khodadoust AA, Franklin RM (1979) Transfer of bacterial infection by donor cornea in penetrating keratoplasty. Am J Ophthalmol 87:130-132

Krachmer JH, Alldredge OC (1978) Subepithelial infiltrates: a probable sign of cornea transplant rejection. Arch Ophthalmol 96:2234-2237

Mason CM, Sugar A, Meyer RF (1984) Intrastromal crystalline deposits following corneal graft rejection. Cornea 3:89-94

Matoba A, Moore MB, Merten JL, McCulley JP (1984) Donor-tohost transmission of streptococcal infection by corneas stored in McCarey-Kaufman medium. Cornea 3:105-108

McCulloch C (1971) Immunosuppression and keratoplasty. Can J Ophthalmol 6:161-169

Meisler DM, Langston RHS, Naab TJ, Aaby AA, McMahon JT, Tubbs RR (1984) Infectious crystalline keratopathy. Am J Ophthaimol 97:337-343

Tuberville AW, Wood TO (1981) Corneal ulcers in corneal transplants. Curr Eye Res 1:479-485

Received July 12, 1985 / Accepted October 30, 1985 